\title{
TARIH VE SiYASETNAMELER ÇERÇEVESINDE KLASIK TÜRK EDEBIYATINDA VEZIR HIKÂYELERi
}

\section{Vizier Stories in Classical Turkish literature within the Frame of History and Politic Books}

\section{Dr. Murat ÖZTÜRK}

ÖZ

Siyasetnameler sultanlara ve diğer devlet adamlarına devlet yönetimiyle ilgili ögüt vermek için yazılan eserlerdir. Yazar/şair bu öğüt ve fikirleri aktarırken tarihte yaşanmış olaylardan ve hafizalarda iz bırakmış yöneticilerden örnekler verir. Bazen konuya uygun kıssalar anlatır ve böylece yöneticilerin tarihî olaylardan ders çıkarmasını ister. Klasik Türk edebiyatında kaleme alınan ve kahramanları sultan, vezir gibi tipler olan pek çok kurgusal eserde de yönetici hikâyeleri anlatılırken tarihî şahsiyetlere telmihte bulunulur ve devlet adamlarına nasihat verilir. Çoğu defa kurmaca dünyanın kahramanlarının maceralarıyla tarihî kişiliklerin yaşadıkları birbirine benzer. Bu durum ahlakî eserlerde anlatılan pek çok hikâyede de kendisini gösterir. Bu makalede de klasik Türk edebiyatının mensur ve manzum hikâyelerindeki vezir tiplerinin maceraları ve görünümleri siyasetname tarzında yazılmış eserlerdeki fikirler ve tarihteki benzer olaylar paralelliğinde ele alınmıştır. Böylelikle klasik dönemde farklı alanlarda yazılan eserlerin edebiyat ve tarih incelemeleri için ortak kaynaklık değerleri ortaya konmaya çalışımıştır.

Anahtar Sözcükler: siyasetname, mesnevi, mensur hikâye, vezir, tarih.

\section{ABSTACT}

Politic books are works written to give advice to the sultans and the other statesmen as regards to the administration of the State. By quoting these advice and ideas, the writer/poet gives examples of some historical events and administrators who have made a mark on the mind. S/he sometimes tell congruous anectodes aimed to lead the administrators to gain experience from the historical events (circumsttances). Within classical Turkish literature in many fictional works protagonists of which are characters like sultans and viziers, the narrators give advice to the administrators by referring to historical important persons. The adventures of the heroes of the fictional world and those of the historical ones frequently resemble each other. This kind of case is also seen in several stories told in the moral works. In this article, the adventures and appearances of the types of viziers in stories written in prose and poems in classical Turkish literature are examined with a parallelism to the ideas written in the works in the form of politicbooks and similar events in history. In this way, the common bibliographical values of the works written in different disciplines in the classical period for investigations of literature and history are tried to be found out.

Key Words: politic books, mathnawi, prose story, vizier, history.

\section{Giriş}

Devlet yönetimi ile ilgili incelikleri öğretmek, sultan/padişahın otoritesini kalıcı kılmak, yöneticilerin reaya ile ilişkilerini istenen düzeyde tutmak, sosyal barışı tesis etmek,

\footnotetext{
*Yüzüncü Yıl Üniversitesi, Eğitim Fakültesi, Türk Dili ve Edebiyatı Öğretmenliği bölümü. muratozturk8@gmail.com
} 
devletin uzun ömürlü ve toplumun huzurlu olmasını sağlamak amaçlarıyla yazılan siyasetnameler, Türk edebiyatının en eski türlerinden biridir. İslamiyet öncesi İran devlet geleneği ve eski Hint yönetim anlayışının İslamî anlayışla harmanlandığı siyasetnameler, asırlar boyunca şairler/yazarlarca genellikle birbirine çok benzer içerikte kaleme alınmışlardır. Arap ve İran devletlerinde yazılan siyasetname geleneği Türk edebiyatında da benzer form ve içeriklerde devam ettirilmiştir. Türün işlevi asırlar geçse de önemini yitirmemiş ve farklı örneklerle günümüze kadar gelmiştir.

İslamî dönem yazılı edebiyatımızın en eski tarihli eseri olan Kutadgu Bilig bir siyasetnamedir. Mesnevi nazım şeklinde yazılan bu siyasetnameden sonra Türk dilinde manzum ve mensur olarak yazılmış çok sayıda siyasetname mevcuttur. Bunlar arasında hikâye tarzında ve hayali kahramanların (bazı eserlerde hayvanların) macera ve diyalogları araç kılınarak yazılan siyasetnameler de vardır. Bu eserler öğretici ve eğlendirici bir fonksiyonu haiz olup hikmet içerirler. Kurmaca ve teorik siyasetnamelerin bir kısmı bizzat devlet adamlarınca bir kısmı ise şairlerce kaleme alınmışlardır. Ayrıca çoğu mesnevi nazım şekliyle yazılan; kahramanları kurmaca dünyadan sultan, şehzade, vezir ve diğer devlet adamları olan eserlerle konuları doğrudan tarihten ve tarihî şahsiyetlerden alınarak yazılan anlatı eserlerinde siyasetnamelerde ele alınan konu ve düşüncelerin yansımaları mevcuttur.*

Siyasetnamelerde devlet yönetiminin nasıl olması gerektiği hususunda başta padişahlar olmak üzere devlet adamlarının dikkatleri adalet, cesaret, maliye, yönetim, ordu, halkla ilişkiler, ilim, cömertlik, istişare gibi konulara çekilmiştir. Ele alınan konulardan biri de vezirlere dairdir. Devlet idaresinde sultanın en önemli yardımcıları olan vezirlerin faaliyetlerinin ve rollerinin önemi hem padişahlara ve şehzadelere hem de bizzat vezirlere siyasetnameler aracılığıla belirtilmiştir. Hatta sırf vezirlere nasihat etmek amacıyla yazılan siyasetnameler de mevcuttur: Defterdar Sarı Mehmed Paşa'nın Nasihatü'l-Vüzera ve'l-Ümera'sı, Nahifi Süleyman Efendi'nin Nasihatü'l Vüzera an Nahifi Efendisi Nev'înin Fazailü'l Vüzera ve Hasâilü'l-Ümera'sı, Nergisi'nin El-Vasfu'l-Kâmil fi Ahvâl-i Veziri'lAdili Lütfi Paşa'nın Asafnamési gibi. Pek çok siyasetnamede vezirlerin kimlerden seçilmesi, vezirlerde ne gibi niteliklerin bulunması ve aranması, devletin varlığı ve bekası için vezirlerin hangi rollere sahip olması gerektiği hususları vurgulanmıştır.

\section{Siyasetnameler ve Anlatı Eserlerinde Dinî-Kültürel Özellikler}

Klasik çağlar boyunca Doğu'da ve Batı'da din merkezli hayat düzeni kurulmuş, devlet ve tebaa arasındaki ilişki çoğu zaman bu anlayışa göre düzenlenmeye çalışılmıştır. Batı’da asırlar boyunca krallıklar üzerinde kilisenin etkisi varlığını kuvvetle hissettirmiş,

* Bu makalede "anlatı"yla bir şair/yazar/anlatıcı tarafından kurgulanan, kaynağı gerçek ya da hayalî olay (vak'a) veya olay zincirine dayalı anlatım; "anlatı eserleri"yle olaya dayalı kurgusal anlatmanın (tahkiye) yapıldığı halk hikâyesi, mensur hikâye, destan, mesnevi, masal gibi türler kastedilmiştir. Bu yönüyle tarihî olayların bir kurguya dayanmaksızın anlatıldığı tarih metinleri ve tarihçiler, özelde Osmanlı tarihçileri, tarafindan yazılan kitaplar (Osmanlı kronikleri) anlatı eseri olarak değerlendirilmemiştir. 
Doğu'da da yöneticiler dinî esaslar üzerinden iktidar alanı oluşturmak istemişlerdir. Örneğin İslam toplumlarında sultan olmak isteyen kişi, adına hutbe okutmuş, kimi sultanlar halifeden meşruiyetinin tanınmasını istemiş hatta zaman zaman halifelere baskı yapmışlardır.

Klasik medeniyette sanatsal ve geleneksel unsurlar tesadüfî değildir. Medeniyeti oluşturan hayat anlayışı sanat eserlerinde de yansımasını bulur. Doğu ve Batı dünyasında mimarîden edebiyata, müzikten resme ve süsleme sanatlarına varıncaya kadar estetik eserlerin büyük çoğunluğunda kültür ve medeniyetin ana özünü oluşturan dinî anlayışın izlerine rastlamak mümkündür. Siyasetnamelerde de din dişı kültürel özellikler bulunsa bile yazarlar/şairler yöneticilere telkin etmeye çalıştıkları adalet, cesaret, dindarlık, merhamet gibi vasıfları Kur'an ve hadisleri temel alarak anlatmış, fikirlerini dinî kaynaklara göndermeler yaparak ispata çalışmışlardır (Atmaca 2000a, Atmaca 2000b, Atmaca 2003, Atmaca 2004).

"Siyasetnameler, esas karakter bakımından ahlakî eserler arasında yer alır; bu türün önemli dallarından biri sayılır. ilk ve orta çağlarda ahlakın temeli din olduğuna göre, siyasetnameler dini esaslara dayanır. Kur'an'dan ve hadislerden tanıklar getirilir; tarihten örnekler verilir. Geçmişteki olayları, zalim ve adil hükümdarlarla devlet ve şeriat adamlarının bu konudaki tutumlarını belirten hikâyeler ve fikralar anlatılır." (Levend 1963: 31).

Siyasetname yazarının hikmetçi tutumu bilgiçlik taslamaktan ziyade uyarmak ve irşat etmektir. Zaten siyasetnameler nasihatname türünün ürünü olup yazarı da nasihati esas alır. Kendisini bu konuda sorumluluk makamında gören yazarlar fikirlerinin sağlamlığını, geçerliliğini ispat gayesiyle meşru bir dayanağa ihtiyaç duyarlar. Bu dayanak hiç şüphesiz Müslüman toplumun benimsediği Kur'an ve hadislerdir. Dinî referansları reddetmek yönetici için düşünülse bile ifade edilebilir olmaktan uzaktır.

Siyasetnamelerde işlenen bu mevzuların manzum-mensur divan edebiyatı hikâyeleriyle halk hikâye ve masallarında da yansıması mevcuttur. Kurmaca âlemin hayali kahramanlarının maceraları aslında siyasetnamelerdeki teorik mevzuların edebî formlardaki yansımalarıdır. Bu anlatılardaki padişahların sağ kolu olan vezirlerin akıllı, bilge, kurnaz, hain, uyanık, sinsi gibi olumlu ve olumsuz özellikleri siyasetnamelerdeki uyarıcı düşüncelerin şerhi gibidir. Tıpkı siyasetname yazarları gibi bazı mesnevi şâirleri ve hikâye yazarları da olayın akışına uygun yerde âyet veya hadislerden iktibas yapar veya dinî kelama telmihte bulunur.

Mesneviler ve mensur hikâyelerdeki motiflerin varlığı, devralınan gelenekten kaynaklanmaktadır. Dolayısıyla bu motifler gelenek içinde ve halk hafızasında güçlü bir şekilde yer etmiş ve sıklıkla işlenmişlerdir. Yüzlerce yıl boyunca birbirine yakın tema ve konuda eserlerin yazılması benzer tecrübelerin tekrarına işaret etmektedir. Aynı şekilde teorik eserler olan siyasetnamelerin de muhteva ve amaç olarak benzerliği bu durumu göstermektedir. Siyasetname yazarlarının bir kısmının bizzat devlet adamı, bilge, tarihçi, şehzade hocası gibi toplum nezdinde makbul bir konumda olmaları yaşanmışlıkların ve öğrenilenlerin kitabileştirilmesini sağlamıştır. Siyasetnamelerde vezirlerin ve diğer devlet adamlarının rolleri ve etkileriyle ilgili olarak teorik çerçevede anlatılan pek çok hususun 
karşılı̆̆ını muhayyel âlemde ve tarih içinde görmek mümkündür. Eski edebiyatımızda yazılan pek çok mesnevide ve mensur hikâyede yine halk masallarının pek çoğunda asıl kahramanları arasında vezirlerin olduğu anlatılara rastlanmaktadır. Bu eserlerde vezirler etrafında anlatılanların siyasetnamelerin paralelinde olduğu ve bir bakıma devrin yönetici-okuyucu-dinleyicilerinin zihinlerini canlı tuttuğu, muhatapların olaylar ve durumlar karşısında tedbirli ve akıllı davranmaya ikna edilmeye çalışıldığı ifade edilebilir. Bu durum muhayyel olanla hakikat arasında ciddi ve güçlü bir bağ olduğunu ve anlatının çoğu zaman bu bağ üzerine inşa edildiğini gösterir.

Bazı hikâyelerde vezir ve sultanlara dair öykülemeler aslında birer siyasetnamedir (Hümayunname, Bahtiyarname, Behiştînnin Heft-Peyker'i, Cinanînnin Cilaü'l-Kulûb'ü vs). Kelile ve Dimne, Tûtiname, Bahtiyarname gibi kaynağı Hint edebiyatı olup Arapça ve Farsça'ya tercüme edilen ve bu dillerden de yeniden kurgulanıp Türkçeye aktarılan eserlerde siyasetname türüne dair anlatılar geniş yer tutar. Mesela, Hümayunnaméde anlatılan çerçeve hikâyelerden bazılarında hayvan masalları örneğiyle devlet yönetimine dair incelikler, fikirler ifade edilir (Bülbül 2009). Hikâyeler ve mesneviler hayalî ve itibari de olsa toplumların yüzlerce yıllık tecrübelerini aktarırlar.

Siyasetname yazarlarının bazıları anlatımı tekdüzelikten kurtarmak, konuyu okuyucu zihninde somutlaştırmak için araya hikâyeler katarlar. Yine bazı mesnevi veya hikâye yazarlarının da hikâyelerini siyasetname tarzında yazmaları bu iki türün işlevsel ilişkisini gösterir. Mesela Vahidî, Tecaribü'l-Insan adlı eserinde: “peygamber, ìskender, Aristo, Batlamyus, Sokrat, Erdeşir-Babek, Kisra, Nizamülmülk, Bâyezid-i Bistami gibi zevatın ibret dolu kıssalarını nakleder." (Uğur 1992: 89). Behiştînnin Heft-Peyker'i, Cinânînnin Cilâu'l-Kulûbu gibi bazı mesneviler ve Hümayunname gibi bazı hikâyeler de öz itibariyle siyasetname kabul edilir. Heft-Peyker'de şâir, kahramanların ağzından İran şâhı Behram'a devlet yönetimiyle ilgili, vakar, cesaret, adalet, cömertlik, siyaset gibi konularda öğüt verir. Anlatıcılar bazen çerçeve hikâyede duruma ve kişiye uygun bir masal ya da hikâye anlatırlar ki böylelikle kültürel kodlar ve tecrübeler başkalarına aktarılır.

Başta aşk konulu olmak üzere mesnevilerde çizilen vezir tasvirlerinin tarihte de benzerleriyle karşılaşılmaktadır. Örneğin hain vezir figürü halifeyi Moğol hanına teslim eden Abbasî veziridir. Kanuni Sultan Süleyman dönemi vezirlerinden olup Mısır'a vali olarak tayin edilen ancak bir süre sonra padişaha isyan ederek kendisini sultan ilan eden Hain Ahmet Paşa gibi. Olumlu özellikleriyle de sivrilen vezir tipleri tarih ve edebiyatta sıklıkla anılır birer telmih kaynağı olmuşlardır. Hz. Süleyman'ın veziri Asaf, ìskender'in veziri Aristo, Gazneli Mahmut'un veziri Ayaz, Selçuklu veziri Nizamülmülk vs. Gerek tarihte yaşanan olaylar ve yaşayan gerçek kahramanlar gerekse kurmaca dünyanın kahramanlarının maceralarının benzerliği ve bu maceraların teorik fikirlerle örtüşmesi bize topluma yön veren söylemin toplumla ilgili her anlatı eserinde olduğunu göstermektedir. Nihayeti itibariyle kültür, toplumun genel kabulleriyle ilintilidir. Dolayısıyla klasik dönemde edebî eserde ele alınan mevzu ve şair/yazarın anlatısı genellikle toplumun benimsediği kültür ve medeniyetin dışına çıkamaz. 


\section{Vezirlerin Genel Özellikleri}

Siyasetnamelerin pek çoğunda yönetici sınıfa verilen nasihatler, yapılan aktarımlar genel özelliklere sahiptir. Siyaset bilimci kimliği taşıyan şair/yazar vezirlere hitap ederken veya sultanlara ne türlü devlet adamları seçmeleri gerektiği yönünde öğütler verirken vezirlerde olması gereken vasıfları da siralar. Esasen tebaadan ve sultana nispetle kul sayılan kişiler olan siyasetname yazarları aynı zamanda halkın yöneticilerle ilgili isteklerinin tercümanı olur.

Siyasetnamelerde vezirlerle ilgili dikkat çekilen olumlu ve olumsuz hasletler klasik edebiyatta mensur ve manzum anlatı eserleriyle bazı ahlakî eserlerde anlatılan hikâyelerdeki vezir tiplerinde de mevcuttur. Bu hikâyelerde vezirlerle ilgili dikkat çekilen başlıca hasletlerin edebî ve tarihî alandaki yansımaları şu başlıklar altında değerlendirilebilir:

\subsection{Akillik}

Hikâyelerde şahların yanında genellikle akil vezirler vardır. İskender'in yanında Aristo, Behram Şâh'ın yanında Büzürcmihr, Vamık u Azra'da Taymus Şah'ın yanında Şadkam, Gazneli Mahmut'un yanında Ayaz bulunur. Bu durum şahlığın ancak akıllı vezirlerle beraber büyüklük kazanacağını gösterir. Osmanlı sadrazamlarından Pîrî Mehmet Paşa, Yavuz Sultan Selim'e devletin çöküşünü üç şeyle açıklarken ilk madde olarak devletin bir ahmak vezir-i azama düşmesini gösterir (Ŭğur 1989: 110). Defterdar Sarı Mehmet Paşa da sultana öğüt verirken konuyla ilgili şöyle der:

\footnotetext{
"Çalışmaların ürününü elde etmek, mal ve yiyecek biriktirmek, deniz gibi hazineler meydana getirmek, evreni yaratan Tanrı'nın emaneti olan reaya fukarasının ve bütün Tanrı kullarının güven ve rahatını, dirlik ve düzenliğini korumaya çalışan, dindar, doğru ve Aristo gibi akıllı bir veziri tam yetkiyle vekil tayin buyurup "emanetleri ehline veriniz" sözü uyarınca yurt işlerinin yoluna konulup düzenlenmesi reayanın hallerinin iyileştirilmesi bu vezire brrakılmalı." (Uğural 1969: 7).
}

On altıncı asır şairi Cinanînin Cilau'-l-Kulûb adlı eserinin ilk üç bölümü sultanlarvezirler ve diğer devlet görevlileri hakkında ve daha çok onlara nasihat babında kaleme alınmıştır. Toplam yirmi bölümden oluşan ve pendname tarzında yazılan eserin ilk üç bölümü aynı zamanda siyasetname türüne örnektir. Eserin ikinci bölümü vezirlere nasihattir. Her nasihat bölümünden sonra konuya uygun bir hikâye anlatan Cinânî, bu kısımda da vezir hikâyeleri anlatır. Cinânîye göre vezirlerin özellikleri özetle şunlar olmalıdır: doğru sözlülük, hayırseverlik, âdillik, müşfiklik, haksızlığa karşı sözünü esirgemezlik, hasetsizlik, örneklik-rehberlik, dindarlık, cömertlik-hamilik, eminlik ve sabırlılıktır. Doksan dört beyitlik siyasetname-nasihatname kısmından sonra ideal ve akıllı vezir örneğine uygun bir hikâye anlatır: Buna göre Mısır'ı alan Nasır lakaplı bir sultan halkın gönlünü kazanmak için ziyafetler verip mescitler yapar, vakıf eserleri bina eder. Bir gün vezir ona Mısır'ın alınması esnasında zarar gören halkın zararlarını tazmin etmesi, esnafa yardımcı olması ve halkın tıpkı eski refah seviyesine çabuk ulaşması için hazinesini açması hâlinde halkın gönlünü büsbütün fethedeceğini, böylelikle reayanın kendisine bağlılıkta ve itaatte kusur işlemeyeceğini tavsiye eder. Padişah vezirin nasihatine uyar ve 
halkın sevgisine mazhar olur. Siyahîler ordusunun Mısır’ı tekrar ele geçirmek üzere saldırısı esnasında padişahtan memnun olan halk bütün gücüyle padişaha ve ordusuna yardımcı olur ve düşmana karşı zafer kazanılır (Özkan: 38. http://ekitap.kultur.gov.tr 12.10.2012). Böylelikle bilge ve devlet muhibbi bir vezirin devletin varlığı ve bekası için ne denli gerekli olduğu hikâyeyle somutlaştırılır.

Gülşehrînin Mantıku't-Tayr'ında anlatılan bir hikâyeye göre, halifenin meclisinde oturan pek çok kişi türlü konularda bilgiçlik taslayarak sohbet ederler. Ancak padişahın akıllı veziri konuşulanların pek çoğunun yalan ve bu kişilerin de yalancı olduğunu iddia ve ispat eder. Vezir, kılık değiştirerek gittiği pazarda süslü bir tacı yere koyar ve bunu bir meleğin getirdiğini söyler. Bunun üzerine pek çok kişi yalan ifadelerle meleğin tâcı nasıl getirdiğini, bunun padişahın saltanatının "kut"una işaret ettiğini anlatırlar. Şehir halkı tâcı alıp halifenin yanına getirir ve yalanlarına burada da devam ederler. Ne var ki olayın mahiyeti bir süre sonra anlaşılınca yalancılar kendilerini aklamaya çalışırlar (Yavuz: 139-147. http://ekitap.kultur.gov.tr 12.10.2012).

Lâmii Çelebi'nin Ferhad ile Şîrîn'inde de Çin Şah'ının yanında akıllı vezir Mülk-ara vardır. Mülkârâ sultanın kaygılarını gidermek üzere çalışır (Esir: 40. http://ekitap.kultur.gov.tr 12.10.2012).

Ahmed-i Rıdvan, Rıdvaniyyésinde Ayaz'ın sâdık ve bilge hâliyle ilgili bir hikâye anlattıktan sonra vezirlerin genel özellikleri hakkında kısa bir değerlendirme yapar. Buna göre vezirler akıllı, âlim, kâmil, iffetli, dindar, ileri görüşlü, anlayışlı, beğenilir ve sağduyulu olmalıdır:

\author{
"Lafzını gördi Ayaz'un ma'nevî \\ Aferinler didi şâh-ı Gaznevî \\ Hem-nişini şehlerüñ âkil gerek \\ Hurde-bîn ü âlim ü kâmil gerek \\ Hem gerekdür iffet ü hüsn ü cemal \\ Hem firaset hem diyanet hem kemal \\ Hem gerek tab' u selim-i huy-ı hûb \\ Hasretü'l-'uşşâk ü mahbûbü'l-kulûb \\ Tâ ki şehler eyleye anı kabûl \\ Haseki ola şehün katında kul” (Yılmaz 2006: 67)
}

Bu akıllı vezir tipleri Kırk Vezir Hikâyelerinde de mevcuttur. Çerçeve hikâyede, üvey annesinin aşk teklifini kabul etmediği için iftiraya uğrayan şehzadeyi babası ve İran şahı olan Hafikeyn öldürtmek ister. Şahın bu teşebbüsü diğer vezirlerin araya girmesi ve her gece vezirlerden birinin şaha kadınların fitneciligiyle ilgili bir hikâye anlatmasıyla akim kalır. Vezirler kırk gün süreyle şahı oyalar ve sonuçta şehzadenin suçsuzluğu anlaşılır (Kavruk 1998: 113).

Mehmed'in lşsk-namésinde de ismi gibi Kâmil olan vezir, sultanın akıl hocası ve güvenilir bir adamıdır (Emlik 2008: 14). Olumsuz açıdan akıllı vezir örneği de hikâyelerde göze çarpmaktadır. Bunlardan biri Zarifînin Mihr ü Mâhındadır. Bu hikâyede Mihr'in babası hükümdar Pervin, kızına âşık olan ve tutsak edilen Mâh'ı öldürtmek isterse de 
veziri araya girerek Mah'ın şarap, sihir ve hükümdarın güzel kızı kullanılarak din değiştirmesinin sağlanması ve böylelikle kızılla evlendirildikten sonra ordunun başına geçirilmesi ve Çin şahı Hilal'in üzerine salınması tavsiye edilir (Turhan 1995: 21).

\subsection{Tevazu ve Tokgözlülük}

Rıdvaniye'de akil, merhametli ve kibirden uzak bir vezir örneği olarak vezir Ayaz'a dair bir hikâye anlatılır. Ayaz her sabah özel mahzenine girip çıkmaktadır. Diğer vezirler kıskanç ve gammaz olup durumu sultana bildirirler. Ayaz'in padişah hazinesinden çaldığı değerli serveti sandığında sakladığını iddia ederler. Sultan, Ayaz'dan herhangi bir hıyanet beklemediğini ifade ederek mahzene girip sandı̆̆ açar ve görür ki bir çift eski çarıkla gayet köhne bir hırka vardır. Ayaz’ı çă̆ırtıp olayın mahiyetini açıklamasını ister. Ayaz her sabah bu eski çarıklar ve hırkayı görerek geçmişteki fakir günlerini yâd ettiğini böylelikle gurur ve kinden uzak durmaya çalıştı̆̆ını anlatır (Yılmaz 2006: 68).

\subsection{Liyakat}

Yusuf Has Hacib hükümdarın, devlet makamları için işinin ehli kişileri seçmesi gerektiğini belirtirken: "Tanrı bir kimseyi mesud etmek ve yükseltmek isterse, ona ehliyetli ve dürüst hizmetkârlar verir. Eğer yükselttiğini tekrar düşürmek isterse, ona gün göstermeyen hizmetkâr verir." der (Türk 2012: 177). Gülşen-i Mülâk yazarı Zaifíde aynı konuya temas eder ve bir de Nuşirevan'ın veziri Büzürcmihr ile ilgili bir kıssa anlatır. "Kıssada belirtildiğine göre, bir gün Büzürcmihr'e içlerinde senin gibi bir bilgin, akıllı bir filozof olduğu hâlde Sasanî hükümdarlarının saltanatı neden çabuk yıkıldı? diye soranlara Büzürcmihr cevap olarak, onlar büyük işleri küçüklere ısmarladıkları için böyle bir sonuçla karşılaştılar." der ( Koçin 2005: 131).

Diyarbakırlı Ahmedînin Yusuf u Züleyha'sında da Hz Yusuf bilgeliği, dürüstlüğü ve yetkinliği nedeniyle vezaret makamına getirilir. Yusuf kısa sürede düş yorumculuğunun da etkisiyle ülkedeki işleri aldığı tedbirlerle düzene sokar. Daha sonra Melik Reyyan, Yusuf u tahtının varisi ilan eder ve ölür.

“Ol Melîk gördi ki gâyet 'aklı var

Hilati geydürüp itdi haznedâr

Her umûrr aña teslîm eyledi

Sen benüm ulu vezîrimsin didi

Hem aña virdi mükemmel bir sarây

Kul karavaş virdi vâfir hûy hây

Hị̧̂ gidermezdi yanından bir sấat

'Aklina fikrine iderdi pesend

Oldı on biş yıl bu hâl ile yürür"

(Kadığlu: 16. http://ekitap.kultur.gov.tr 12.10.2012)

Çerçeve hikâye içine yerleştirilen ve on bölümden oluşan Bahtiyarnaménin tamamı eğlenceli ve merak unsuru taşıyan hikâyelerden oluşur. Eser bu hikâyelerle beraber kompozisyonu ve muhtevasıyla tür olarak bir siyasetnamedir. Beşinci bölümde anlatılan bir hikâyede haset ve makam düşkünü vezirlerle sâdık ve yetenekli vezirin sultanla olan 
ilişkileri hikâye edilir. Adaleti ve merhametiyle meşhur vezir Ebu Temmam, Erran ve Ermenistan ülkesine gelip yerleşir ve kısa sürede şâhın takdir ve iltifatını kazanarak onun danışmanı olur. Bir süre sonra şahın dört veziri Ebu Temmam'ı kıskanır ve makamlarını kaybedecekleri endişesiyle ona iftirayla oyun etmeye kalkışırlar. Fakat ilk oyunları ters teper. Çin padişahının kızını istemek üzere yola çıkan Vezir Ebu Temmam fağfurun yanına vardığında hal ve davranışları, aklı ve konuşmasıyla vezaret makamına ne denli layık olduğunu kanıtlar (Ruşen 1994: 87-101).

Bir siyasetname olan Gülşen-i Müluk'ta da liyakat ehli yerine ehil olmayan zalim yöneticilerin sultan tarafından iş başına getirilmesinin yol açacağı sıkıntılarla ilgili bir kıssaya yer verilir. Kıssada âdil bir padişahın ülkesinde göreve getirilen zâlim idarecilerin ettiği zulümler neticesinde halkın, şahının zalim ancak idarecilerinin âdil olduğu bir ülkeye olan göçleri konu edilir ve sultanın yakın çevresinin makam ehli olması gerektiğine dikkat çekilir (Koçin 2005: 116).

Osmanlı'da ilk kez bir padişahın (Genç Osman'ın) kul taifesi tarafindan katline ve dolayısıyla iktidar boşluğu nedeniyle asayişsizliğin baş gösterdiği bir döneme tanıklık eden Koçi Bey, Sultan IV Murat'a sunduğu Risale'sinde devlet makamlarına ehliyetsiz kişilerin getirilmesinin devlet kurumlarının bozulmasına, bütçenin sarsılmasına, isyanların ve keyfiliklerin artmasına, rüşvetin yaygınlaşmasına, ulemanın ilimden uzaklaşmasına neden olduğunu belirterek padişaha uyarıda bulunur (Danışman 1993). Koçi Bey'in bu tespit ve değerlendirmelerinin benzeri divan şâiri Nev'izâde Atayînnin Hamsésinde mevcuttur. Nev'izâde Atayî yazmış olduğu beş mesneviyle on yedinci asır Osmanlı toplum ve düşünce dünyasına ayna tutar. Onun eserleri hem tarihî hem de sosyolojik veriler sunması itibariyle kıymet taşır. Hamse, Nevizâde Atayînnin içinde yaşadığı dünyanın doğrudan ve dolaylı yansımalarıyla doludur. Eserlerine Osmanlı, özel olarak ìstanbul ve Rumeli'yi mekân olarak seçen Atayî, buralarda karşılaştı̆̆ı bürokratik sorunları, rüşvet, adam kayırma, ehil olmayanlara mansıp verilişi, genel asayişsizlik, medreselerin yozlaşması, çeşitli meslek gruplarının görevlerini suistimal edişi gibi konularla ilgili pek çok ayrıntıyı araya bazı küçük hikâyeler de katarak bugüne taşıyacak şekilde aktarır (Kortantamer 1993: 89-151). Atayînin Koçi Bey'in Risalésindeki anlatılarla paralel tasvirleri ve panoramik tablo çizimleri tarihî metinlerle edebî metinlerin paralel çalışmalar açısından ortak kaynaklık teşkil edeceğini kanıtlamaktadır.

Edebiyat metinlerinin tarih kaynağı olarak kullanılmasının temellerini atan Köprülü, belge ve metin karşılaştırması yaparak çok yönlü bir araştırmacı profili çizmiștir. Bir tarihçi olarak onun en önemli mirası ve ayrıcalıklı konumu edebiyat metinlerindeki ayıntıları tarihsel akış içerisindeki bağlamlarına oturtma, sürekli belge ve metinleri karşılaştırma çabasında yatmaktadır (Kuru 2008: 22) . Osmanlı tarihçisi Cornell H. Fleischer de Köprülü'nün yöntemini benimseyenlerdendir. Fleischer, edebî metinlerin tarihe kaynaklık edişi ve değerine dikkat çeker:

“Osmanlı Imparatorluğu üzerine modern araștırmacıllıta, anlatı kökenli, özellikle de edebî nitelikte kanitlara güvenmeme, arşiv belgelerine dayalı, kişisellikten arındırılmış "katı" verileri ya da "olgusal" anlatıları yeğleme ĕgilimi vardır. Böyle bir güvensizlik ya da bu kaynakların içerdiği öznellikten korku duymak yalnızca yersiz değil, aynı zamanda ciddi bi- 
çimde kısıtlayıcıdır. "Yumuşak" kanıtlar, tıpkı yumuşak dokular gibi, katı yapılara can ve anlam kazandırır." (Fleischer 1996: 2-3).

Bu türden çalışmalar için en uygun isimlerden biri olan tarihçi, şair, yazar ve bürokrat Gelibolulu Mustafa Ậli, yaşadığı dönemde pek çok ehliyetsiz kişinin lâyıkı olmadıkları makamlara getirildiklerini ifade ederek sultanı bile tenkit eder ve durumu "Şehbaz yuvasının alçaktan uçan karga yavrusuna verilmesi”ne benzetir (Şeker 1997: 143).

\section{4. Ödüllendirilmişlik}

Siyasetname yazarları padişahlara emrindekilerin hizmetlerini ödüllendirmeleri gerektiğine dair nasihatlerde bulunurlar. Arapça yazdığı eserinde Muhammed bin Turtuşi hükümdarların iyisi ve kötüsüne dair başlıklı bölümde Ömer bin Hattab'dan şunları aktarır: "Üç şey hakikaten talihsizliktir: Bir komşu ki iyilik yaptığında saklar, senin bir kötülügüüü gördüğünde hemen bir fısıltıyla yayar. Bir kadın ki evde iken başının etini yer, evde olmadığında ne yaptığından emin olmaz. Bir hükümdar ki hoş muamele etsen seni övmez, hizmette kusur etsen seni hemen öldürür.” (Türk 2012: 63).

Veyse vü Ramin mesnevisinde olumlu vezir örneği mevcuttur. Ramin'e İran'a doğru yaptığı yolculuğu esnasında yardımcı olan Behzad'dır. Behzad, Ramin'e gönülden hizmet etmiş ve bu sebeple âdil ve ideal bir hükümdar olan Ramin tarafından ödüllendirilmiştir (Öztürk 2009: 539-568). Tıpkı Tursun Beğ'in: “Hükümdar, saltanata şükrederek insanlara adl göstermeli, hizmet edenlerin hakkını bilmeli, memleketin genişliğine bakarak raiyetin emlâkine tama etmemeli, zulme uğramışlara adaletle yetişmeli, reayanın evlerine asker yerleştirmekten mümkün mertebe kaçınmalıdır." nasihatine uymuş gibi (Inalcık 1958: 68-79). Hizmetlerinden ve sadakatinden ötürü vezirlik makamına getirilenlerden biri de Süheyl ü Nevbahar mesnevisindeki Nakkaş'dır. Nakkaş, hikâye boyunca Süheyl'e yakınlığı, yardımı ve bilgeliği nedeniyle mutlu sona kavuşan âşıklarca vezaret makamına getirilmiştir. Yine Süheyl ve Nakkaş'ın tutsak edildikleri Yun şehrinde kendilerini kurtaran Zindancı daha sonraları bu şehre vali olarak tayin edilir (Dilçin 1991:6975).

Yazarı tespit edilememiş yerli mensur eserlerden biri olan Letaifnaméde akıllı ve kötü huylu vezir hikâyeleri vardır. Bu hikâyelerde vezirler tıpkı diğer pek çok hikâyedeki gibi birer tiptirler. Kötü huylu vezir azl ile uzaklaştırılırken akıllı vezir şahın işlerini kolaylaştırır (Eren 2008: 285-300).

Pek çok aşk mesnevisinde âşık kahramanların yanı başında bulunan sadık tipler aynı zamanda devlet yönetimi açısından son derece önemli olan akıl, bilgi, tecrübe, feraset, uyanıklık, insan-ı kâmil ve soğukkanlılık gibi olumlu özelliklerin temsilciliğini yaparlar.

\subsection{Hainlik ve iftiracılık}

Defterdar Sarı Mehmet Paşa vezirleri kıskançlık ve garazkârlık hususunda uyarır: "Padişah kendisinden gayrı bir kimseye sevgi gösterirse kıskanıp onun mertebesine ulaşma ve haysiyetini kırma yoluna gitmeyeler. Ve kin ve garez etmeyeler. İstek ve arzularını elde etmek için padişahları sıkıştırmayalar." (Uğural 1969: 24). 
Ahmed-i Rıdvan'ın Hüsrev ü Şirin'inde hâin ve haset vezir tipinin iki ayrı örneği vardır. Bunlardan birisi Türk hakanı Sâye Han'ı yenen komutan Behram'a iftira edip Hürmüz Şâh'ın kendisine hakaret dolu bir mektupla beraber aşağılayıcı hediyeler göndermesine neden olan, bu yüzden de Hürmüz Şâh'ın, Behram ve arkadaşlarının kararıyla tahtı bırakmaya mecbur olmasına neden olan vezirdir:

$$
\begin{aligned}
& \text { "Meger varidi şâhuñ bir vezîri } \\
& \text { Ki yogidi habâsetde nazîri } \\
& \text { Degüldi hâtırı Behrâma mâyil } \\
& \text { Hasûdâne düzetdi bend-i müşkil } \\
& \text { Didi şâhâ anuñ gönderdiginüñ } \\
& \text { Degül biñde biri ol aldugınun } \\
& \text { Şehe kıldı eser bu kavl-i mekkâr } \\
& \text { Ki tammâ' idi gaddâr u sitem-kâr } \\
& \text { Dahı han oglı da gamz itmişidi } \\
& \text { lçinden niçe remz[i] dimişidi” }
\end{aligned}
$$

(Tavukçu: 321. http://ekitap.kultur.gov.tr 12/10?2012)

ikinci hain vezir tipi de oğluna babasını öldürten vezirdir. Bu vezir hem zalim hem sinsi hem de haindir. Perviz'in oğlu Şiruye, sinsi vezirin ve diğer devlet erkânının tesiriyle babasını kendi hançeriyle öldürüp tahta geçer.

$$
\begin{aligned}
& \text { “Vezîri var idi bir zulm-pîşe } \\
& \text { İşi hayf idi âlemde hemîşe } \\
& \text { İle zulmile uzatmışidi dest } \\
& \text { Kamu serverleri itmişidi pest } \\
& \text { Yıkılmışdı ser-â-ser mülk-i îrân } \\
& \text { Ki şehr ü rûstâ olmışdı vîrân” }
\end{aligned}
$$

(Tavukçu: 511. http://ekitap.kultur.gov.tr 12.10.2012)

Lamii Çelebi'nin Veyse vü Ramininde iki ayrı vezir tipi vardır. Bunlardan birincisi Horasan hakanı Keyhan Şah'ın başveziri olup hikâyenin başkahramanlarından Ramin'in Veyse'ye kavuşmasını engelleyip hapse atılmasına ve delirmesine neden olan kişidir. Amacı Ramin'i kendi kızı Gülşeker'le evlendirmek ve böylece yönetimdeki rolünü perçinlemek olan vezir, Keyhan Şah'ın ölümünden sonra da Çin fağfurunu Horasan ülkesine davet edip devletine ihanet eder. Kısa bir süre saltanat sürse de Ramin'in adamları tarafından öldürülerek hainliğinin bedelini öder (Öztürk 2009: 574).

XVl. Yüzyılın başında Sıdkî mahlaslı Seyyit Ahmed bin Hasan Bâlî tarafından Farsçadan Türkçeye tercüme edilen mensur hikâye Hikâye-i Ucube ve Mahcube'de de farklı vezir tipleri mevcuttur. Eserdeki hikâyelerden birinin konusu özetle şöyledir:

"Bir âdil padişah vardır. Veziri içinde gizlice zulüm barındırmaktadır. $O$ şehirde mutlu bir hoca vardır. Öldügünde geriye malı ve oğlu kalır. Vezir, âdil padişahtan o malı hazinesine almasını ister. Şah yetim hakkı yemeyi reddeder. Vezir kendi kendine bir hile yapmayı planlar. Vezir şahtan 
intikam almak için şahın düşmanına bir mektup yazar. Memleketi almak için uygun zaman olduğunu söyler. Düşman, melikin üzerine yürür ama yenilir. Adil melik esir olan şahı öldürmez. Taht altında kuyu kazıp saklar. Vefasız vezir, şah uyuyunca esir şahı çıkarıp şahtan intikam alması için eline kılıç verir. Düssman, şahı öldürecekken onun kendi canını bağışladığı, vezirin kendi padişahına ihanet ettiği aklına gelir. Düssman, veziri ihaneti yüzünden öldürür. Şahı uyarır. Vezirin yaptıklarını anlatır. iki melik dost olur. Âdil melik şehri süsletir, ziyafet verir. Diğer meliki ülkesine gönderir. Böylece melik adalet ve insaf ile düşmanın gazabından kurtulur." (Malgaca 2006: 37).

Bu hikâyedeki vezirin ölen kişinin malını almak istemesi Yavuz'la defterdarı arasında geçtiği rivayet edilen münasebeti akla getirmektedir. 'Mısır'ın zaptından sonra, muazzam bir servet terk ederek ölen bir tâcirin metrukatından bir kısmına el konulması, defterdarlıkça uygun bulunuyordu. Pâdişaha gönderilen takrire Yavuz, kendi kalemiyle şunları yazmıştı: "Müteveffaya rahmet, malına bereket, evladına âfiyet, gammaza la'net!" (Ayverdi 1999: 262).

Hikâye-i Ucube ve Mahcubéde anlatılan başka bir hikâyede de padişahın yakınlık duyup ödüllendirdiği bir genci kıskanan bir vezirin ettiği iftira neticesinde yaptığı haksızlığın kendisine dönüşü ve can verişi anlatılır (Malgaca 2006: 30).

Aslı İranlı şair Nizamîyye ait olan ve pek çok şairce yeniden biçimlendirilip kurgulanarak Türkçeye aktarılan Heft Peyker mesnevilerinde İran'ın eski meşhur şahlarından Behram-ı Gûr'un hayatı ve faaliyetleri anlatılır. Bu mesnevinin aslında da tercümelerinde de hain ve kötü vezir tipi vardır. On altıncı asır şairi Abdînin mesnevisi buna örnektir:

"Behram bir gün divanda iken bir haberci gelir. Çin hakanının askerleriyle Iran'a yürüdügünü, birçok şehri yakıp yıktıgını söyler. Behram bu haberi duyunca çok üzülür. Hazine bos, asker dagınıktır. Sah içip eglenmekle vaktini geçirmis, yeni vezir ise haksızlık ve hırsızlıkla halkı kırmıstır. Vezir her zaman halkın edepsiz, küstah oldugunu, yoksul kalması ve baskı altında tutulması gerektiğini şaha söylemiştir. Behram derdini dağıtmak için ava çıktı̆̆ı sırada bir duman görerek atını oraya sürer. Dağları aşıp dumanın çıktığı yere varır. Bir köpeğin ağaçta asılı olduğunu görerek oradaki ihtiyara sebebini sorar. Ihtiyar şu cevabı verir: "Bu köpek benim koyunlarımın bekçisi idi. Bir yere gittigim vakit sürüyü ona emanet ederdim. Bir gün koyunlarımı sayınca, yedisinin eksik olduğunu gördüm. Koyunlar günden güne eksiliyor, bir kısmını da zekât adı altında "âmil-i sadakat" alıp götürüyordu. Bir gün uykuya dalmıştım. Gözlerimi açınca bir kurdun yaklaştığını gördüm. Köpeğin sürüden semiz bir koyun seçerek kurda verdiğini gördüm. Artık durumu anlamıştım. Bir süre sabrettim, sonunda köpeği böyle astım. Emanete hryanet edenin hali budur" (Hikâyenin bu kısmı Metin Eren'in derlediği bir masalla benzeşmektedir (Eren 2001: 284-286)).

Bu hikâyeyi ihtiyar çobandan dinleyen Behrâm ibret dersi alır. Şehre dönünce durumu inceleyerek kararını verir. Ertesi gün tahta oturup divanı toplar. O sırada gelip yerine kurulan vezire şiddetle çıkışıp yaptığı kö- 
tülüklerinden dolayı onu kınar ve zindana attırır. "Kimin sikâyeti varsa gelsin" diye ilan ederler. Herkes divana koşar, zindandakiler de çıkarılır. Bunlardan yedisi şahın huzurunda gelip şikâyetlerini anlatırlar. Bu yedi mazlumdan birinin kardeşi işkence ile öldürülmüş, ikincinin bağına el konulmuş, üçüncünün cevherleri elinden alınmış, saz çalan dördüncünün sevgilisi zorla alınmıș, beşincinin malı mülkü gasp edilmiş, sipahi olan altıncının köyü elinden alınmıs, bir sofu olan yedincinin de, vezire kötü dua eder korkusuyla elleri bağlanmıștır. Şah, vezir tarafindan zindana atılan bu zavallılara kaybettikleri malları ve değerleri geri verir. Vezirin mallarını da mazlumlardan yedincisi olan sofuya bağışlarsa da, o bunu kabul etmeyip gözden kaybolur. Behrâm'in o gece gözüne uyku girmez. Sabah olunca şah darağacımı kurdurur; herkesi toplar, zincire bağlı veziri de getirterek astırır. Adalet dersi aldığı çobanı da çă̆ırtarak ihsanlarda bulunur. Memleket huzura kavuşmuş, hazine dolmuş, asker de düzene girmiştir. Çin hakanı bu olayları duyunca yaptı̆̆ına pişman olur ve özür diler. Vezirin yazdığı mektupları gönderir. Meğer hakanı şah aleyhine kışkırtan da vezir imiş. Behrâm içki ve eğlenceyi bırakır. Yedi köşsü yedi tapınak haline getirir." (Güzelova 2008: 148).

Hüsrev ü Şirin mesnevilerinde sâdık ve hain vezir tipleri mevcuttur. Hamidizade Celilî́nin yazdığı Hüsrev ü Şirin'de Hüsrev'in oğlu Şiruye hain ve fitneci vezir tarafindan kandırılarak baba katili yapılır. Bu cinayetten sonra İran ülkesi ve kisraların saltanatı yıkılır (Kazan 1997. http://ekitap.kultur.gov.tr 12.10.2012).

Hikâyelerdeki ihanetin sebeplerinin belki de en önemlisi iktidar hırsıdır. Tıpkı sultanlar gibi vezirler de devlet içindeki konumlarını kaybetmemek hatta pekiştirmek veya canlarını kurtarmak için mücadele verirler. Bu kaygının tarih sayfalarına da geçmiş pek çok örneği mevcuttur.

Abbasî halifesi Mu'tasım'ın, veziri ibnn-i Alkamînin de içinde bulunduğu ihanet grubunca kandırılıp Moğol komutanı Hülagu'ya teslim edildiği ve Moğol askerlerinin tekmeleri altında can verdiği rivayet edilir (Özdemir 2005: 135-169). Bu durumun benzerlerini Osmanlı tarihinde görmek mümkündür (Bozbirlik 2004: 51-69). Osmanlı devlet yönetiminde bürokrasinin zaman zaman saltanattan daha baskın rol oynadığı, bürokratların da sultan azl ve halleriyle konumlarını sağlama almaya çalıştıkları bilinmektedir (Afyoncu vd. 2010). Sultan IV Murat'ın saltanatı döneminde Recep Paşa ve adamları Hafiz Ahmed Paşa'yı katlederken, Sultan 1. Mustafa döneminde de Mere Hüseyin Paşa iktidarını sürdürmek için onlarca kişinin katline sebep olmuştur (Afyoncu vd. 2010: 96-99). Yine Osmanlı tarihinde Genç Osman (11. Osman)a karşı muhalefetin önde gelenlerinden ve hatta katlin birinci derecede sorumlularından Davut Paşa da benzer eylemleri icra etmiştir. Ne var ki yeni padişah zamanında etkili olmaya başlayan asker ve bürokratların faaliyetleriyle Davut Paşa önce Genç Osman'ın bindirildiği arabaya bindirilir, Genç Osman'ın boğdurulduğu Yedikule'de aynı yağlı urganla boğularak katledilir (Çağatay 1992: 222). Tarihçi Bostanzade Yahya Efendi, Kara Davut Paşa'nın yeni bir taht değişikliğini engellemek ve 1. Mustafa'nın ölmesi hâlinde bizzat saltanatı ele geçirmek için Osmanlı soyunun kökünü kazımak istediğini belirtir. Müellife göre, veziriazam öncelikle 1 . Ahmet'in hayattaki şehzadelerinin en büyüğü olan Murat'ı ortadan kaldırmak istemiş ve bu 
işi Bâb-ı Hümayun ağalarından birisine ihale etmişti (Afyoncu vd. 2010:252). Nitekim bu faaliyette bulunmak isteyen kapı ağası içoğlanlarınca öldürülür.

Hain ve sinsi devlet adamına Osmanlı tarihindeki en dikkat çekici örneklerden biri olarak İsfendiyaroğlu Şemsi Paşa gösterilebilir. Paşa Osmanlı tarafindan ortadan kaldırılan bir beyliğin soyundan gelmektedir. Uzun yıllar Osmanlı Devleti hizmetinde bulunan Şemsi Paşa, Osmanlı'ya karşı duyduğu kini padişaha kırk bin flori rüşvet verdikten sonra bizzat ifade eder. Tarihçi Gelibolulu Ali'nin bu konudaki kaydı şöyledir:

“Koçi nâm kethüdasını bu kıssadan âgâh idüb mâ-vaka'a her ne ise söyledi. "Lillahi'l-hamd Âl-i Osmânîden Kızıl Ahmedli'nin intikamın aldım." deyu şükr eyledi. Hatta müellif-i fakir anda hazır bulunub "ne vechile intikamın aldınız" didikde "Padişâhı rüşvete tatındurdum. Hatta bugün kırk bin sikke mikdarı bir büyücek lokma tatdırdım. Ba'de hâzâ ne pâdişah rüşvet almakdan ferâgat ider ne rüşvetle mülki pâydâr olub kendüsi ikamet eyler. Anlar bizi mülk-i mevrûsumuzdan niçe dûr itdiler ise ankarîb ben de anlarun kâr u bâr-ı saltanatından mehcûr olmalarına sebeb oldum." deyu tafsîl itdi" (Çerçi 2000: 252).

Bu vezirlerin önemli bir kısmı canlarını vererek yaptıklarının karşılı̆ını ödemişlerdir. Vezir hikâyelerinde hainliği ve hırsıyla saltanat ve devleti zarara uğratanların öldürülmesi, görevlerine son verilmesi siyasetname yazarlarının da vurguladığı olması gereken bir durumdur. Nitekim başta Osmanlı olmak üzere ihanet ve ihmalleri görülen onlarca vezir görevlerinden veya canlarından olmuşlardır.

\subsection{Sinsilik}

Mevlana'nın Mesnevisinde Yahudi'yken Hristiyan gibi görünen ve aslında tam bir Hristiyan düşmanı olan bir vezirin hikâyesi ve fitneciliği anlatılmaktadır. Bu hikâyenin didaktik örüntülü Türkçe çevirisi on beşinci asır şairlerinden Muiniddin Murad tarafından kaleme alınmıştır. Yahudi padişahın hilekâr Yahudi veziri, Hristiyan olduğu için Yahudi padişahtan işkence görmüş rolü yapar ve Hristiyanlarca samimi bir kişi olarak makbul bulunur. Halk ona gönülden inanır. Vezir, daha sonra onların içine attığı fitne tohumlarıyla Yahudi devlet içinde yaşayan İsevileri birbirine düşürür ve kendi dininin saltanat ve gücünü pekiştirmiş olur (Yavuz. http://ekitap.kultur.gov.tr 12.10.2012).

Benzer içerikteki bir Bitlis masalında da Müslüman gibi görünüp boynunda haç taşıyan ve vezirlik makamında bulunan altı keşişin sinsiliği anlatılmaktadır (Eren 2001:284286).

Moğolların ilhanlı veziri Sadü'ddevle iki yıl süreyle devletin tepesinde bulunmuş ve pek çok Fars ve Moğol unsuru yönetimden uzaklaştırmış bir Yahudi'dir. Kaynaklar Sa'düddevle'nin bilhassa maliye politikalarının başarılı olduğunu, ilhanın güvenini kazandığını, ancak Yahudi kimliği ve zaman zaman Yahudiciliği gibi nedenlerle Müslüman halkın öfkesini topladığını bildirirler. Bir gayrimüslimin Müslüman toplumda vezir olması ona şüpheyle bakılmasına neden olmuş, iktidar çekişmeleri nedeniyle bu özellik Yahudi vezirin sonunu hazırlamıştır (Uyar 2003: 226-242). Yukarıda hem Mevlana'nın hikâyesi ve Muiniddin Murad tarafından yapılan çevirisinde hem de masalda anlatılanlar 
gayrimüslim birine devletin yani emanetin teslim edilmesine ìslam toplumunda iyi gözle bakılmadığını yine tarihî gerçeklerle izah etmektedir.

\subsection{Nasihatçilik}

Hüsrev'in akıllı ve bilge veziri Büzürcmihr olumlu vezir tipinin yansımasıdır. Behram'ın işgalinden kurtulan ülkeyi vezir Büzürcmihr; saltanat, taç ve tahtıyla Husrev'e teslim eder ve bazı nasihatlerde bulunur: Adaletten ayrılmamasını, yüksek makamlara alçak insanları getirmemesini, fakirlerin parasıyla hazinesini doldurmamasını, yetimlerin gözyaşını gördüğü hâlde kese kese gümüş biriktirmemesini, süse heves etmemesini, içkiye düşkün olmamasını söyleyerek öğütlerde bulunur (Kazan 1997: 32-33. http://ekitap.kultur.gov.tr 12/10/2012).

Cinânînin mensur eseri Bedâyiül ÂAsârın elli birinci hikâyesinde taht kavgası veren iki şehzadenin mücadelesi anlatılırken nasihat makamında bulunan vezirlerden de bahsedilir. Buna göre Hint ve Sind padişahı Cumhur, oğlu küçükken ölür. Emirler ve âlimler toplanarak saltanata sultanın kardeşinin getirilmesini isterler. Kardeş May tahta çıkar ve sultanın eşiyle evlenir ve bu evlilikten Telhend dünyaya gelir. Telhend iki yaşındayken sultan ölür. Bu kez sultanlık çocuklar büyüyünceye kadar annede kalır. Çocuklar büyüyünca taht kavgası başlar. Kardeşlerden küçük olan Telhend daha hırslı ve zalimdir. Saltanat yolunda her engeli aşmayı meşru görür. ilkin kardeşiyle haberleşip saltanattan vazgeçmesini teklif eder. Aynı teklifi kardeşi Kev de kendisine yapar. Hatta Kev, Telhend'e reayanın boş yere kan dökmemesi ve eziyet çekmemesi yönünde telkinde bulunur; ancak umduğu sonucu alamayınca savaşmaya karar verir. Kev, vezirinin de tavsiyesiyle fitnenin kendisinden çıkmaması için askerlerini ve beylerini uyarır. Hatta savaş öncesinde askerlerine ilk ok atan ve kılıç çekenin kendileri olmamaları hususunda uyarılarına devam eder. Telhend, savaşta kardeş ve kural tanımadan saldırır; ancak bir müddet sonra rüzgârın etkisiyle oturduğu filin üzerindeki karargahı devrilir ve bağırıp çağırmalarını duyan olmaz. Savaş meydanında susuzluktan can vererek ölür. Telhend'in öldügünü ispat ve teşhir eden Kev, sultanlık makamına erişir. Daha sonra oğlunun ölümüne üzülen anne sultanı teskin ve teselli etmek üzere vezirleri tarafından satranç oyunu icat edilir (Ünlü 2008: 348-353). Bu hikâye adeta Osmanlı ülkesinde şehzade kavgalarının kurgusal atmosfere nakledilmiş hâli gibidir.

\subsection{Müzevvirlik}

Cinânînin Bedayi'ül Asar’ında elli ikinci hikâyede müzevvir bir vezirin haraç vermekte olan Turan şahı Cemşid'i İran şahı Piruz Şah'a haraç vermemesi hususunda içkili bir anında ikna etmesi ve sonrasındaki mücadeleler anlatılır. Cemşid Şah, vezirin iknasıyla yeterli gücü olmadığı halde Piruz Şaha karşı gelir en sonunda yapılan savaşı cadıların yardımına rağmen kaybeder. Bütün bu hallere sebep olan vezir ölümle cezalandırılır. Cemşid Şah af diler ve haraç vermeyi kabul etmek şartıyla bağışlanır (Ünlü 2008: 354).

Ahmedî aynı zamanda siyaset tarihine örnek olan eserinde Abbasî ve Moğol hükümdarlarının saltanat yıllarına ve kısa biyografilerine değinir. Moğol hükümdarı Ahmed Han'ın saltanatı esnasında Argun Han'ın ortadan kaldırılmasının saltanat açısından önemli olduğunu düşünerek fitne uyandırmaya çalışan vezir Ziya'ü'l-Mülk'ün sonraki 
sultan Argun Han zamanında cezalandırılıp katledilişini de anlatır (Akdoğan: 410-415. http://ekitap.kultur.gov.tr 12.10.2012).

\subsection{Zalimlik ve Açgözlülük}

Defterdar Sarı Mehmet Paşa Nesayihü'l-Vüzera'sında vezirlere dair olumsuz bazı özellikleri sıralarken onları aç gözlü olmamaları konusunda uyarır:

"Padişah hizmetini hemen mal toplamaya vesile saymayıp, padişahın özel mallarını ve köyler halkı ile askerin kamu mallarına karşı açgözlülük etmeyeler. Kanaatkar olup aç gözlülükten ve ceza gününü düşünüp Tanrı́nın kahredici gazabından çekinmek gerektir. Zira mal toplama ve saklama, sahibini dünyada huzursuz, hesap gününde sorulacak soruları cevaplandırmada güçsüz kılar, azap çektirir ve pişman eder." (Uğural 1969: 24).

Ahmed-i Rıdvan Rıdvaniyyésinde padişaha adalet telkin etmek için dokuzuncu hikâyede zalim padişah Dahhak-ı Tâzînin hikâyesini anlatırken onun zalimliğinden ötürü omzunda iki yılan çıktığından bahseder. Aynı hikâyede Nemrut'un sivrisinekle yaşadığı olay ve Firavun'un boğulması hadisesiyle Yezid, Haccac ve Timur'dan da bahsedip bu kişileri zulümle anar (Yılmaz 2006: 54-55).

Bu hikâyedeki vezir tipini Ahmedî iskendernamésinde tanıtır. Ahmedî̀ye göre de bir sultan ne kadar güçlü ve zeki olursa olsun istişare ettikleri kendilerine verilen mansıba layık değilse sultanı da ülkeyi de felakete sürükler.

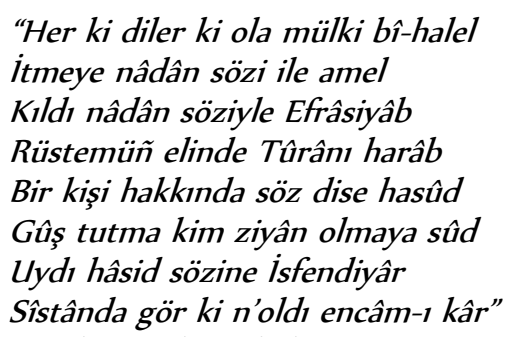

(Akdoğan: 50. http://ekitap.kultur.gov.tr 12.10.2012)

Gelibolulu Mustafa Âlî Riyazü's-Salikin adlı eserinde bir vezirin tama gözünün ve rüşvetçiliğinin kendisinin azline sebep olduğunu dile getirdiği azliyyesinde yahut arz-1 hâlinde bu işin padişahtan bilindiğini ifade eder:

$$
\begin{aligned}
& \text { Fâyik olan azl ile giryân ola } \\
& \text { Fâsık alup mansıbı şâdân ola } \\
& \text { Eller ider zulmi gider adl u dâd } \\
& \text { Şâh-ı cihândan bilinür ol fesâd } \\
& \text { Çünki vekîl-i Hak olan şâhdur } \\
& \text { Gayrı vekîl itmesi ikrâhdur } \\
& \text { Haşr olıcak kendüden eyler su'âl } \\
& \text { Adl ile zulmün sebebin Zül-celâl }
\end{aligned}
$$


Zulmi iden gerçi ki düstûrdur

Şâh-ı cihân define me'mûrdur

Özri mülûkun niçe makbûl ola

Eller ide cevri o mes'ûl ola

Cürm ü günâhum yog iken hâsılı

Dûzah-ı azlün olıcak dâhili (Arslan-Aksoyak: 37.http://ekitap.kultur.gov.tr 12.10.2012)

Gelibolulu Âlî, eserinin sonunda Büzürcmihr, Bermekiler, Nizamülmülk, Pîr Muhammed gibi ünlü vezirlerin adaletlerinden ve devlet için önemlerinden bahsederken, kendi devrindeki vezirlerin adaletsiz olduğunu kaydederek devrin padişahını da dolaylı yollardan eleştirir (Arslan-Aksoyak: 217-218. http://ekitap.kultur.gov.tr 12.10.2012).

Cinanînin Cilau'l-Kulûb'undaki bir hikâyede de sadrazamlık makamına getirilen akıl$l_{1}$, tedbirli ve sâdık bir vezirin bir müddet sonra gurura kapılıp halka nasıl eziyet ettiği, ne şekilde servet edindiği, adaletten uzaklaştığı ve halkın nefretini kazandığı, neticede isyan eden halkın veziri öldürmeye teşebbüs ettiği, olanların padişaha intikalinden sonra da cezalandırılıp başını verdiği anlatılır (Özkan: 48-50 http://ekitap.kultur.gov.tr 12/10/2012). Hikâyedeki bu durumun gereğine uygun şekilde Osmanlı Devleti'nde de vezirler sadaret makamında genellikle çok uzun süre tutulmazlardı. Zira uzun süreli görevlerde vezirler devlet içinde nüfuzlarını artırıp, keyfiliğe yönelebiliyorlardı. Nitekim sultan III. Ahmet, halefi I. Mahmut'a saltanatı teslim ettiğinde onu bu konuda uyarıp şöyle der: "Oğlum! Baban cennet-mekân Sultan Mustafa Han-ı Sâni hazretleriyle ben sırf vüzerâmıza teslimiyet gösterdiğimiz için şu senin cülûs ettiğin (çıktığın) tahttan sükût ettik (düş̧ük). Sen bizden ibret al. Kendini vüzerânın nüfûzu altına sokma. Her şeyi onlara bırakma. Kendin gör ve anla." (Mignot (aktaran) Altınay 2010: 102).

Cinanînin hikâyesindeki vezir tipinin cezalandırılması gerektiğiyle ilgili tarihçi ve devlet adamı Tursun Beğ de tespitlerde bulunur. "Hükümdarlar, vezir ve emirlerini de halka zulüm yapmaktan alıkoymalıdır. Ayrıca padişah evlat ve akrabaları da halkı ezmemelidirler. Halktan vergiler belirli zamanlarda meselâ mahsul mevsimlerinde toplanmalıdır. Böylece onlar hazırlıklı olurlar ve sıkıntıya düşmezler... Her hususta halkın yararı göz önünde tutulmalıdı" (Özcan (aktaran: Altay) 2008: 78).

Yukarıda akillik başlığı altında Cinanînin Cilaul Kulub'undaki bir başka hikâye özetlenmişti. Gerek Gelibolulu Mustafa Âlî̉nin başından geçen mansıp hadisesi ve tarihteki gerçek şahsiyetlere adalet kavramı etrafında gönderme yapması gerek Ahmedînnin teorisi gerekse Cinanînin eserindeki teorik çerçevenin biri olumlu diğeri olumsuz iki vezir hikâyesiyle örneklendirilip somutlandırılması siyasetnamelerin kurgusal dünya paralelindeki anlatımı açısından önemlidir. Bu ve bunun gibi eserlerde anlatııı/şair/yazar hikâye ve kıssa türlerinin fonksiyonlarına müracaat ederek hem anlatımını etkili kılmaya çalışır hem de yöneticiden beklenen ideal tavrın nasıl olması gerektiği hususunu dolaylı yoldan bizzat muhataba iletmiş olur. Klasik dönemde bu eserlerin tamamına yakınının aynı zamanda devrin padişah, şehzade, vezir, paşa gibi yönetici kesimine sunulması halinde de eser aracılığıyla uyarı ve beklentiler aktarılmış oluyordu. 
Hikâye kurgusu içinde bir siyasetname olan Behiştînnin Heft-Peyker'indeki hikâyelerinden birinde Çin güzeli, Behrâm Şah'a devlet yönetiminde siyasetin önemine dair ögütler verdikten sonra konuya uygun başka bir hikâye anlatır. Hikâyede Çin'de ulu bir şahın halka eziyet eden vezirinin yaptıkları ve nihayetinde ölümle cezalandırılması anlatılır (Demirel 98-100).

Mensur ve manzum kurgusal eserlerde anlatılan hikâyelerle ibretlik kıssalardaki ödül ve ceza ilişkisi anlatıdaki her şeyin iyi ve kötü arasındaki ideal insanı anlatmak için olduğunu düşündürmektedir.

\subsection{Danışmanlık}

Siyasetname tarzında yazılan eserlerin hemen hepsinde Kur'an-1 Kerim'deki “(Yapacağın) işlerde onlara da danış, bir kere de azmettin mi, artık Allah'a dayan”. (Al-i İmran, 159), "Rablerine icabet edenler, namazı dosdoğru kılanlar, işleri kendi aralarında şura ile olanlar ve kendilerine rızık olarak verdiklerimizden infak edenler...” (Şura-38), "Ey ileri gelenler! Durumum hakkında bana görüş bildirin. Sizler yanımda olmadıkça hiçbir işe kesin olarak karar vermem" (Neml-32) mealindeki âyetler de referans gösterilerek sultana, danışmadan iş yapmaması gerektiği tavsiye edilir.

Klasik Türk edebiyatında vezirlere dair anlatıların bulunduğu mesnevilerin büyük çoğunluğunda sultanın yanında aklı başında, yol gösterebilen, sıkıntılı durumlarda sultana çözüm üreten bir vezir bulunur. Mesela Ahmedî ìskender'in hayat macerasını siyasetname kurgusunda anlattığı iskendernamésinde Aristo, Bukrat, Eflatun ve Sokrat'ı ìskender'in vezirleri ve danışmanları konumuna yerleştirir. (Akdoğan: http://ekitap.kultur.gov.tr 12.10.2012). Behiştînin Heft-Peyker'inde de Misır güzeli, Behram Şah'a iskender'in cihanı fethetmek fikri üzerine Aristo'ya danıştığına dair bir hikâye anlatır (Demirel: 107-111. http://ekitap.kultur.gov.tr 12.10.2012). Veyse vü Ramin'de Padişah Ramin'e ögütler veren Şeyh, onu akıllı ve bilgin kişilere danışarak iş yapması ve böyle kişileri seçkin makamlara getirmesi yönünde uyarır:

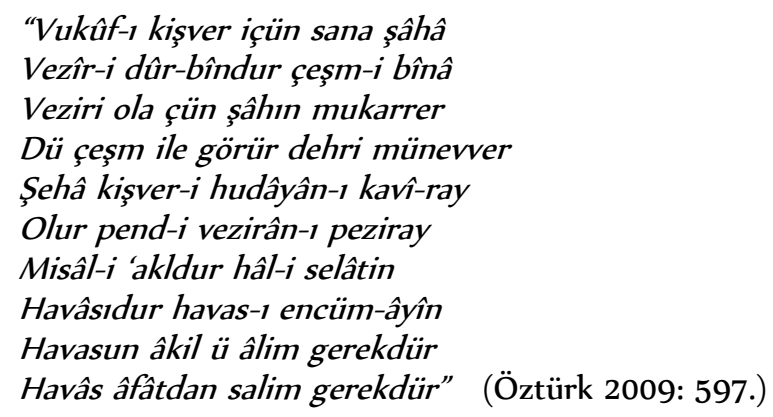

Veyse vü Ramin'de Ramin'in yanında Pervane ve Behzad bulunur. Lamii Çelebi'nin Ferhad ile Şîrîn'inde de Çin fağfuru oğlu Ferhad'ın derdine çare ararken vezirine danışmak gereği hisseder. 
"Var idi bir vezîri kâr-dîde

Hired-mend u kavî-rây u güzîde

Ne meh mihr-i felek-mahzar gibi bil

Okurdı ana Mülk-ârâ adın il

Bir işde kim geldi hâna teşvîş

Ona tanışmadan itmezdi bir iş

Ki hem Ferhâda ol idi atabeg

Severdi anı Ferhâd atadan yeg (Esir: 40

http://ekitap.kultur.gov.tr 12.10.2012).

\subsection{Rekabet ve Kıskançlık}

Tarihi kayıtlar hemen her dönemde vezirler arasında iktidar mücadelesi olduğunu kaydeder. Vezaret makamını elde etmek isteyen vezirler, rakiplerini alaşağı etmek için kadrolaşmış, kadroların beraber hareket etmesiyle sultan üzerinde nüfuz oluşturmaya çalışmışlardır. Söz konusu duruma örnek olarak Osmanlı Devleti'nin gelişme dönemi ve özellikle de duraklama sonrası dönemi örnek gösterilebilir (Bozbirlik 2004: 59-61). Tahtlarından indirilen padişahların ardından yeni padişahın yanında yer alanlar, eski padişahı devirmek için yeniçeri, ulema veya sipahilerle iş birliği yapanlar, elde ettikleri gücü muhafaza etmek ve rakiplerini pasifize etmek için ölüm, azil veya sürgün gibi yollara başvurmuşlardır.

Koçi Bey'in anlattıklarına bakılırsa Osmanlı devlet yönetiminde 1574 yılından sonra sadrazamların tam istiklali son bulmuş, bu tarihten sonra vezirlerin birbirleri ve diğer devlet adamları aleyhindeki iftiraları ve sultanı kışkırtmaları neticesinde nice kıymetli ve hizmet ehli yönetici, çoğu hayatlarına kastedilmek suretiyle, görevlerinden uzaklaştırılmıştır. Koçi Bey bu kişilere Ferhat Paşa, Nasuh Paşa, Yemişçi Hasan Paşa ve Kara Mehmed Paşaları örnek verir (Danışman 1993: 16-17).

Mensur çeviri eserlerden olan Bahtiyarname, çerçeve hikâye içine yerleştirilmiş hikâyelerden oluşmaktadır. Eserde Acem padişahının on kıskanç vezirinin şehzadeyi öldürtmek üzere şahı ikna etmeye çalışması, şehzadenin de padişahın kendisini öldürtmemesi hususunda anlattı̆̆ı on hikâye bulunur (Kavruk 1998: 33). Eserin beşinci bölümünde anlatılan hikâyede de makamlarını kaybetme ve padişahın gözünden düşme kaygısı taşıyan dört vezirin gözde vezir Ebu Temmam'a iftira etmeleri ve bu iftira sonucunda Ebu Temmam'ın canından oluşu anlatılır (Ruşen 1994: 89-100).

\section{Sonuç}

Siyasetnameler genel olarak ideal devlet yönetiminin nasıl olması gerektiği fikri üzerine kaleme alınmışlardır. Toplumsal hayatın hangi esaslar doğrultusunda düzenlenmesi gerektiği üzerine kafa yorulurken bir bakıma sultanların ya da genel olarak yöneticilerin hata yapmaya aday oldukları bu bakımdan da ikaza muhtaç oldukları belirtilmiş olur. Geleneksel anlatının öne çıkan hususlarından biri de dinleyici veya okuyucuyu doğruluğa yönlendirmek, ideal insan modelini örneklendirmektir. Bu düşünce dünyayı güzelleştirme fikri ve adalet isteğiyle ilintilidir. Siyasetnamelerde yönetici sınıfın ideal özellikleri açıklanırken benzer şekilde kurmaca dünyanın yöneticileri de aynı paralelde bir role 
büründürülür. Örneğin pek çok mesnevide sultanlar ve şehzadeler ya her yönüyle makbul ya da adalet ve iyiliğin kıymetini hatırlatacak kadar olumsuz kahramanlardır. Yukarıdaki vezir hikâyelerinde ihanet eden vezir tipi aynı zamanda gafil sultanın da varlığına işaret eder. Yine vezirlerin ihanet, kibir veya sinsilik gibi olumsuz eylemleri neticesinde ettiklerini bulmaları ideal insan tipinin iyi-kötü çatışmasındaki kötü tipin cezalandırılmasını gösterir. Akıllı vezir ise daima makbul ve memduhtur. Anlatıcının ya da kurgulayıcının dünyasında ödülünü övgülerle almıştır. Benzer duruma masallarda da rastlanmaktadır.

Siyasetname ve hikâye (mesnevi) yazarlarının bir kısmının tarihçi olması, toplumun hafızasında yer eden asırlık tecrübelerin yönetici kişilere tekrar tekrar hatırlatılmasına vesile olmuştur. Tarihçinin tarihî gerçeklikleri birer ibret verici ahlakî esere dönüştürmesi yaşanmışlıkların hayat dersi olarak edebî eserde yer bulması açısından önem arz eder. Kurmaca dünyanın tipleri çoğu zaman bu yaşanmışlıklardan mülhem kahramanlardır. Bu yönüyle manzum ya da mensur eserlerdeki siyasete dair hikâyeler, kurgusal metinlerin pek çoğunun reel âlemin dışından gelmediğini göstermektedir. Netice itibariyle gelenek denilen şey asırlık tecrübelerin ve kabullerin toplum zihninde biçimlenip tasdik edilmesidir. Dolayısıyla edebî gelenekteki anlatıların ve muhayyel kahramanların yaşanmışlıklardan yola çıkılarak oluşturulduğunu söylemek mümkündür.

Asırlar süren bir anlatı ve kurgu geleneğinin ürünü olan klasik Türk edebiyatında edebî metinler medeniyetin diğer sanatsal ve fikri unsurlarıyla paralel bir gelişme göstermiş ve varlığı da bu çerçevede sürmüştür. Nitekim divan edebiyatının edebiyat âleminden büyük ölçüde çekilmesi de yeni bir medeniyet ve hayat anlayışına geçişle olmuştur. Bu bakımdan farklı alanlarda yazılan eserleri, türleri ve bu eserlerdeki anlatıları paralel okumalarla incelemek tür ve eserle ilgili anlam çerçevesinin genişliğini ortaya koymak için şarttır.

\section{KAYNAKÇA}

AFYONCU, Erhan, Ahmet ÖNAL, Uğur DEMiR. Osmanlı İmparatorluğu'nda Askeri i̇syanlar ve Darbeler. İstanbul: Yeditepe yay, 2010.

AKDOĞAN, Yaşar. Ahmedî-ískendername. http://ekitap.kultur.gov.tr 12/10/2012.

ALTAY, Ahmet. Düstûru'l-Mülk Melikü'l-Vezir. Selçuk Ünv, SBE yüksek Lisans tezi, Konya: 2008.

ALTINAY, Ahmet Refik. Lale Devri 1718-1730. İstanbul: Tarih Vakfi Yurt yay. 2010

ARSLAN, Mehmet - AKSOYAK, i. Hakkı. (Gelibolulu Mustafa Ali). Riyazu's-Sâlikin. http://ekitap.kultur.gov.tr 12/10/2012.

ATMACA Veli. "Hadisleri Bakımından Siyâsetnâmeler-1 (Siyâset ve Siyâsetnâmeler Hakkında Genel Bilgiler)". Fırat Üniversitesi ilahiyat Fakültesi Dergisi, V, 357-370, 2000a.

ATMACA Veli. "Hadisleri Bakımından Siyâsetnâmeler-ll, (Ebu'n-Necîb ve en-Nehcetü'l- Meslûk fi Siyâseti'l-Mülûk'u)". Fırat Üniversitesi ilahiyat Fakültesi Dergisi, V, $2000 b$.

ATMACA Veli. Hadisleri Bakımından Siyasetnameler-III, (Ebû'n-Necib'in en-Nehcu'l- Meslûk'unda Yönetilenlerle ilgili Rivâyetler)". Fırat Üniversitesi ilahiyat Fakültesi Dergisi, 8, 45-58, 2003.

ATMACA Veli. "Hadisleri Bakımından Siyasetnameler-IV, (Ebû'n-Necib'in en-Nehcu'lMeslûk'unda Yönetenlerle ilgili Rivâyetler)". Fırat Üniversitesi Sosyal Bilimler Dergisi, 14:1, 165-187, 2004.

AYVAZOĞLU, Beşir. Aşk Estetiği İslam Sanatlarının Estetiği Üzerine Bir Deneme. İstanbul: Ötüken yay, 1996. 
AYVERDi, Samiha. Türk Tarihinde Osmanlı Asırları. İstanbul: Kubbealtı Neşriyatı, 1999.

BizBiRLiK, Alpay: “Kroniklerde Osmanlı Devleti Yöneticilerine Yapılan Eleştiriler Üzerine (Başlangıçtan XVl. Yüzyılın Sonuna Kadar)", Bilig, Güz / 2004, Sayı 31.

BüLBüL, Tuncay. Gazi Üniversitesi, Sosyal Bilimler Enstitüsü, Hümâyûn-Nâme (İnceleme-Tenkitli Metin), Doktora Tezi. Ankara: 2009.

ÇERÇi, Faris. Gelibolulu Mustafa Âlî ve Künhü'l-Ahbâr'ında Il. Selim, III. Murat ve IIl. Mehmet Devirleri (II. Cilt). Kayseri: Erciyes Üniversitesi yay. 2000.

DANIŞMAN, Zuhuri. Koçi Bey Risalesi. İstanbul: MEB yay. 1993.

DEMiREL, Şener. Behişti'nin Heft-Peyker Mesnevisi. http://ekitap.kultur.gov.tr 12/10/2012

DilçiN, Cem. Mes'ud Bin Ahmed Süheyl ü Nevbahar, Inceleme-Metin-Sözlük. Ankara: Atatürk Kültür Merkezi yay. 1991.

EMLiK, Mehmet. Mehmed'in lsk-Nâme Adlı Mesnevisinin Günümüz Türkçesiyle Nesre Çevrilmesi ve Mesnevideki Eğitim Unsurları. Konya 2008: Selçuk Üniversitesi, SBE, yüksek lisans tezi.

EREN, Aslı. Letaifname (Dil İncelemesi ve Metin). 2008: İnönü Ünv. SBE, yüksek lisans tezi, Malatya.

EREN, Metin. Bitlis Masalları Üzerine Bir Araştırma.: Van YYü, basılmamış yüksek lisans tezi. 2001.

ESiR, Hasan Ali. Lamii Çelebi, Ferhad ile Şirin. http://ekitap.kultur.gov.tr 12/10/2012

FLEiSCHER, Cornell H. Tarihçi Mustafa Ali (çev: Ayla Ortaç). İstanbul: Tarih Vakfi Yurt Yay.,1996.

GÜZELOVA, Hanzade. Abdînin Heft Peyker Mesnevîsi (İnceleme-Metin-Dizin). Hacettepe Üniversitesi Sosyal Bilimler Enstitüsü, Doktora Tezi, Ankara. 2008.

iNALCIK, Halil. "Osmanlı Padisahı". Ankara Üniversitesi Siyasal Bilimler Fakültesi Dergisi, Cilt XIIl, Sayı 4, Ankara: 1958.

KADIOĞLU, İdris. Diyarbakırlı Ahmedî, Yûsuf u Züleyha (Inceleme-Metin Dizin-Sözlük). http://ekitap.kultur.gov.tr 12/10/2012.

KAVRUK, Hasan. Eski Türk Edebiyatında Mensur Hikâyeler. İstanbul: MEB yay., 1998.

KAZAN, Şevkiye. Hamidizade Celilî Hayatı, Eserleri, Edebî Kişiliği ve Hüsrev ü Şirin Mesnevisi (Inceleme-Tenkitli Metin). Süleyman Demirel Ünv. SBE, yüksek lisans tezi, lsparta: 1997.

KOÇiN, Abdulhakim. Za'ifî Gülşen-i Mülûk. Ankara: Akçağ yay. 2005.

KORTANTAMER, Tunca. Eski Türk Edebiyatı Makaleler. Ankara: Akçağ yay. 1993.

LEVENT, Agâh Sırrı. "Siyasetnâmeler". Türk Dili Araştırmaları Yıllığı, Ankara: Türk Tarih Kurumu Basımevi, 1963.

MALGACA, Eflak. Sıdkî'nin "Hikâye-ì Ucûbe Vü Mahcûbe” Adlı Eseri Ve Eserdeki Eğitimle ilgili Unsurların Tespiti. Dokuz Eylül Üniversitesi, Eğitim Bilimleri Enstitüsü, basılmamış yüksek lisans tezi, İzmir: 2006.

MUSTAFA NURi PAŞA (Haz: Neşet Çağatay). Netayicü'l-Vukuât. Kurumları ve Örgütleriyle Osmanlı Devleti. Ankara: Türk Tarih Kurumu yay. 1992.

ÖZCAN, Abdulkadir. “Osmanlı Siyasetnâmelerinde Reaya Hukuku” Türklerde İnsani Değerler ve İnsan Hakları: Osmanlı İmparatorlugu Dönemi: 1l. Kitap. İstanbul: Türk Kültürüne Hizmet Vakfi. yyy.

ÖZKAN, Mustafa. Cinânî, Ciläü'l-Kulûb (Giriş - Inceleme - Metin - Sözlük). http://ekitap.kultur.gov.tr 12/10/2012.

ÖZDEMiR, H. Ahmet, “Tâhirü'l-Mevlevî ve Cengiz ve Hülâgû Mezâlimi Adlı Eseri”. Sakarya: Sakarya Üniversitesi ilahiyat Fakültesi Dergisi 11 / 2005, s. 135-169.

ÖZTÜRK, Murat. Lamii Çelebi'nin Veyse vü Ramin Mesnevisi (Inceleme-Metin-Sadeleştirme). Atatürk Üniversitesi, SBE, yayımlanmamış doktora tezi, Erzurum: 2009. 
Tarih ve Siyasetnameler Çerçevesinde Klasik Türk Edebiyatında Vezir Hikâyeleri TAED $49 * 93$

RUŞEN, Muhammed. Lüm'atü's-Sirac Li Hazreti't-Tac (Bahtiyarname) (çev: Abdusselam BilgenBetül Bilgen). Ankara: Kültür Bakanlı̆̆ yay.1994.

ŞEKER, Mehmet. Gelibolulu Mustafa Ali ve Mevaidü'n-Nefais fi Kava'idi'l-Mecalis. Ankara: Türk Tarih Kurumu Yay. 1997.

TAVUKÇU, Orhan Kemal. Ahmed Rıdvan'ın Hüsrev ü Şîrîn Mesnevîsi. http://ekitap.kultur.gov.tr $12 / 10 / 2012$.

TURHAN, Vedat. Zarifî ve Mihr ü Mah Mesnevisinin Tenkitli Metni ve İncelemesi. Atatürk Ünv., SBE, yüksek lisans tezi, Erzurum: 1995.

TÜRK, H. Bahadır. Çoban ve Kral Siyasetnamelerde Ideal Yönetici İmgesi. İstanbul: iletişim yay. 2012 .

UĞUR, Ahmet. Osmanlı Siyasetnameleri. Erciyes Üniversitesi Yay, Kayseri 1992.

UĞURAL, Hüseyin Ragıp. Te'lif-i Muhammed Paşa El-defteri Nesayih'ul-Vüzera ve'l-Ümerâ veya Kîtab-Güldeste Nizâm-ı Devlete Müteallik Risale. Ankara: Türk Tarih Kurumu basımevi, 1969.

UYAR, Mustafa. "ilhanlı Devletinde Yahudi Bir Vezir: Sa'düddevle”. Tarih Araştırmaları Dergisi, $\mathrm{XXI} / 33,2003$.

ÜNLÜ, Osman. Cinânînin Bedâyiü'l-Âsâr'ı-İnceleme ve Metin. Ege Üniversitesi Sosyal Bilimler Enstitüsü doktora tezi. İzmir: 2008.

YAVUZ, Kemal. Gülşehri'nin Mantıku't-Tayr'ı (Gülşen-nâme), Metin ve Aktarma. http://ekitap.kultur.gov.tr 12.10.2012.

YAVUZ, Kemal. Mu'ini'nin Mesnevi-i Muradiyye'si. http://ekitap.kultur.gov.tr 12.10.2012

YILMAZ Nebi. Ahmed-i Rıdvan ve Rıdvaniye'si. Ankara Üniversitesi, SBE, yayımlanmamış yüksek lisans tezi. Ankara: 2006. 